\title{
ИНГИБИРОВАНИЕ АЦЕТИЛХОЛИНЭСТЕРАЗЫ ИЗ ЯДА КОБРЫ ПРОПИДИЕМ
}

R. RABA, A. AAVIKSAAR. KOBRA MORGI ATSETOULKOLIINESTERAASI INHIBEERIMINE PROPIIDIUMIGA

R. RABA, A. AAVIKSAAR, PROPIDIUM INHIBITION OF COBRA VENOM ACETYLCHOLINESTERASE

Исходя из данных по флуоресцентному титрованию ацетилхолинэстеразы (АХЭ, КФ 3.1.1.7) из электрического органа Torpedo californica дийодидом пропидия П. Тейлор с сотрудниками $[1,2]$ сделали вывод, что пропидий взаимодействует с этим ферментом исключительно в т.н. периферическом анионном центре связывания катионных лигандов для аллостерической регуляции активности ацетилхолинэстераз. В соответствии с этим дийодид пропидия выступил в реакции АХЭ с ацетилхолином как неконкурентный ингибитор активности фермента [']. Это указывает на то, что пропидий может быть использован для определения роли периферического анионного центра в ацетилхолинэстеразном катализе.

В настоящей работе исследовалось влияние пропидия на параметры Михаэлиса $V_{m}$ и $K_{m}$ в реакции АХЭ из яда кобры (Naja naja oxiana) с ацетилхолином. Фермент был выделен гельфильтрацией на сефадексе $\mathrm{G}-50$ и очищен до гомогенного состояния аффинной хроматографией $\left[^{3}\right]$. Активность фермента определялась на pH-стате TTT2/SBR3/ABU12 фирмы «Radiometer» титрованием освобожденной в ходе гидролиза ацетилхолина уксусной кислоты щелочью (КОН) при $25^{\circ} \mathrm{C}$ и $\mathrm{pH} 7,5$. Влияние дийодида пропидия (препарат фирмы «Calbiochem», использовался без дополнительной очистки) на скорости ферментативного гидролиза ацетилхолина исследовалось при двух значениях ионной силы раствора: $I=0,04 \quad(\mathrm{KCl})$ и $I=0,22 \quad(0,04 \quad \mathrm{M} \quad \mathrm{KCl}$ и 0,1 М $\mathrm{KCl}+0,04 \mathrm{M} \mathrm{MgCl} 2$ соответственно). Значения $K_{i}$ были вычислены из зависимостей наблюдаемых $K_{m}$ от концентрации добавленного ингибитора.

Из графиков зависимостей обратной скорости гидролиза ацетилхолина от его обратной концентрации в присутствии различных концентраций дийодида пропидия видно (см. рисунок), что как при большой, так и при малой ионной силе все прямые Лайнуйвера-Берка пересекаются на оси ординат в одной точке, т. е. имеет место чисто конкурентное ингибирование активности фермента.

Кроме различия в типе ингибирования, отмечены различия и в численных значениях экспериментальных констант ингибирования. Для $\mathrm{AXЭ} \mathrm{из} \mathrm{яда} \mathrm{кобры} \mathrm{нами} \mathrm{получены} K_{i}=3 \cdot 10^{-5} \mathrm{M}$ при $I=0,22$ и $K_{i}=4 \cdot 10^{-6} \mathrm{M}$ при $I=0,04$, в то время как для АХЭ из электрического органа Torpedo californica в сопоставимых условиях получены $K_{i}=3,8 \cdot 10^{-6} M$ при $I=0,23$ и $K_{i}=3,2 \cdot 10^{-7} M$ при $I=0,001$ [']. Эти результаты показывают, что АХЭ из яда кобры, в отличие от синапти- 


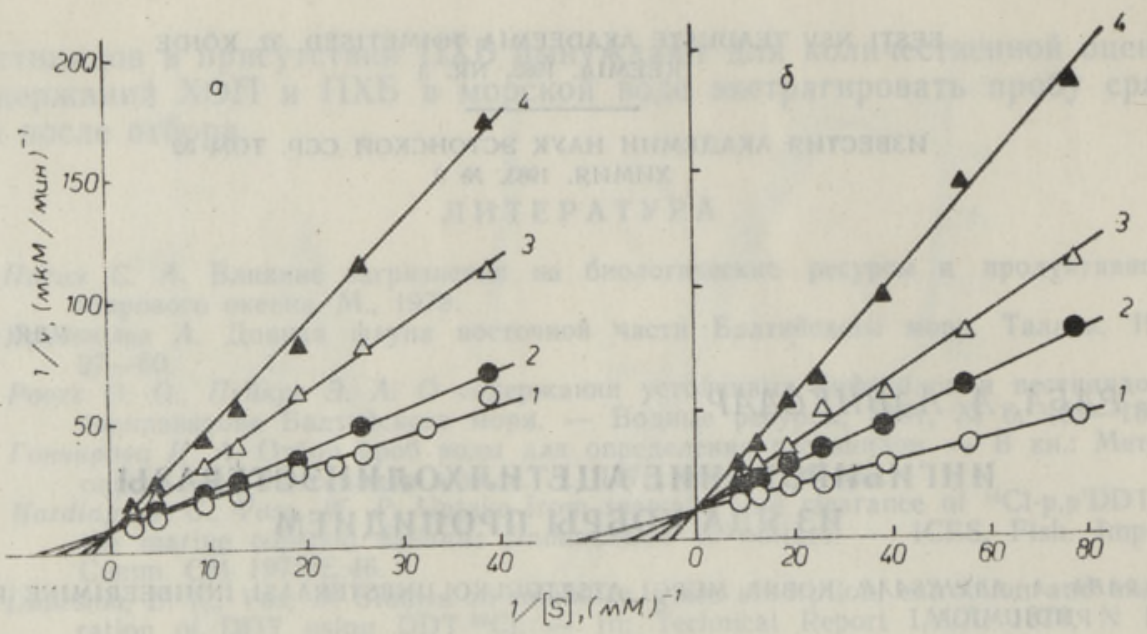

Влияние дийодида пропидия на скорость ферментативного гидролиза ацетилхолина под действнем ацетилхолинэстеразы из яда кобры. Температура $25^{\circ}, \mathrm{pH} 7,5$. a - ионная сила раствора $0,22\left(0,1 \mathrm{M} \mathrm{KCl}\right.$ и $\left.0,04 \mathrm{MgCl}_{2}\right)$, концентрации дийодида пропидия: $0(1), 5,0^{\circ} 10^{-6}(2), 2,5 \cdot 10^{-5}(3)$, $5,23 \cdot 10^{-5}$ M (4). б - ионная сила раствора $0,04(\mathrm{KCl})$, концентрации дийодида пропидия: 0 (I), $1,05 \cdot 10^{-6}$. (2), $2,10^{-10^{-6}}(3), 4,19 \cdot 10^{-6} \mathrm{M}$ (4).

ческих форм фермента, по всей вероятности, не имеет периферического центра для специфического связывания иона пропидия, а его меньший на порядок величины ингибирующий эффект обусловлен взаимодействием лиганда с каталитически активным центром фермента.

Из структурных особенностей АХЭ из яда кобры обращает на себя внимание тот факт, что ее молекулярный вес 67000 уступает молекулярному весу минимальных каталитически активных субъединиц тканевых ацетилхолинэстераз приблизительно на 20000 дальтонов (см., напр., $\left.\left[{ }^{3}\right]\right)$. С другой стороны, показано $\left[{ }^{4-7}\right]$, что при ограниченном трипсинолизе и последующем денатурировании субъединиц тканевых ацетилхолинэстераз додецилсульфатом натрия в присутствии 2-меркаптоэтанола от них отщепляется пептид с молекулярным весом около 20000 , а активированный серин каталитического центра (меченый диизопропилфторфосфатом) располагаетея в оставшейся части молекулы фермента, молекулярный вес которой около 60000 . Возможно, что аллостерический анионный центр у тканевых ацетилхолинэстераз находится именно на этом фрагменте молекулы, а АХЭ из яда кобры является представителем активной «фундаментальной единицы» [3] ацетилхолинэстераз, лишенной аллостерического центра регулирования каталитической активности.

\section{ЛИТЕРАТ У РА}

1. Taylor, P., Jamson, L.-M., Lappi, S., Rademacher, J. Propidium, a fluorescence probe for peripheral anionic site on acetylcholinesterase. - Molec. Pharmacol,, 1974, $10,703-708$.

2. Taylor, P., Lappi, S. Interaction of fluorescence probes with acetylcholinesterase. The site and specificity of propidium binding. - Biochemistry, 1975, 14, $1989-$ 1997.

3. Raba, R., Aaviksaar, A., Raba, M., Siigur, J. Cobra venom acetylcholinesterase. Purification and molecular properties. - Europ. J. Biochem., 1979, 96, 151158.

4. Rosenberry, T. L., Chen, Y. T., Bock, E. Structure of $11 \mathrm{~S}$ acetylcholinesterase, Subunit composition, - Biochemistry, 1974, 13, 3068-3079. 
5. Dudai, Y., Silman, I. The molecular weight and subunit structure of acetylcholinesterase preparations from the electric organ of the electric eei. - Biochem. Biophys. Res. Communs, 1974, 59, 117-124.

6. Morrod, P. J., Marshall, A. G., Clark, D. G. Structural stability and composition of acetylcholinesterase purified by affinity chromatography from fresh electroplax tissue of Electrophorus electricus. - Biochem. Biophys. Res. Communs, 1975, 63, 335-342.

7. Massoulié, J., Bon, S., Rieger, F., Vigny, M. Molecular forms of acetylcholinesterase. - Croatica Chem. Acta, 1975, 47, 163-179.

Институт химической и биологической физики Академии наук Эстонской ССР
Поступила в редакцию 28/III 1983 